\title{
Application of Cane Ash on Compressive Strength of Soil Uncovered to $\mathrm{MgSO}_{4}$
}

\author{
Mark Mikhail, Amin Chegenizadeh, Mahdi Keramatikerman, Geoffrey Burns, Sergei Terzaghi, \\ Hamid Nikraz
}

\begin{abstract}
UCS) were conducted to examine effect of the Sugarcane Bagasse ash (SCBA) on compressive behavior of clay stabilized with cement, mixed with various cane ash contents, when uncovered to magnesium sulphate $\left(\mathrm{MgSO}_{4}\right)$. The analysis showed an enhancement in the range of $10 \%$ to $35 \%$ for control specimens and an enhancement of $60 \%$ to $180 \%$ for magnesium sulfate exposed specimens. Scanning electron microscopic (SEM) analysis also showed interaction of clay and cement particles with sulphate confirming the results in the laboratory.
\end{abstract}

Keywords: Sulfate Attack; UCS; Clay; Cement; Bagasse Ash

\section{INTRODUCTION}

Population rate is growing rapidly throughout the world, and urbanization is expanding on weak soils that require enhancements. There have been many studies on soil properties (Al-Rkaby et al. 2016) .The problematic soils usually containing a high amount of clays, sediments, and peats (Chegenizadeh et al. 2018; Mohamad et al 2016). Usage of geo-grid, by-product and fibres in soil studied in many research (Chegenizadeh and Nikraz 2011a; 2011b, 2011c; 2012; Sabbar et al. 2017; Al-Rkaby et al. 2017; Hasan et al. 2015)

Magnesium sulfate attack occurs when the sulfate component devastates the hydration products that causes a reduction in strength and solidness of the soil containing cement. There are various types of chemical naturally in the environment, however, the magnesium sulfate is the most harmful to soils that containing cement mixtures (Kalıpcilar et al. 2016). Snedker and Temporal (1990) indicated that a road showed $150 \mathrm{~mm}$ elevation, which was due to exposure to about $0.4 \%$ sulfates. Further than that, there is another example when transverse bumps were recorded on street

Revised Manuscript Received on March 17, 2020.

* Correspondence Author

Mark Mikhail*, was with Curtin University Bentley Campus in Perth, Western Australia (e-mail: mark.mikhail@undergrad.curtin.edu.au).

Dr. Amin Chegenizadeh, is with Curtin University, Perth, Western Australia (Corresponding author,e-mail: amin.chegenizadeh@curtin.edu.au).

Dr. Mahdi Keramatikerman, is with Arup Australia, Queensland, Australia. (e-mail: mahdi.keramati@arup.com).

Geoffrey Burns, is a Geotechnical Lead with Arup Australia, Queensland, Australia. (e-mail: geoffrey.burns@arup.com).

Sergei Terzaghi, is a Geotechnical Lead with Arup America, Los Angeles, USA. (e-mail: sergei.terzaghi@arup.com).

Professor Hamid Nikraz, is with Curtin University, Perth, Western Australia (e-mail: h.nikraz@curtin.edu.au).

(C) The Authors. Published by Blue Eyes Intelligence Engineering and Sciences Publication (BEIESP). This is an open access article under the CC BY-NC-ND license (http://creativecommons.org/licenses/by-nc-nd/4.0/) asphalt due to the development of sulphate inside the cement stabilized base course (Rollings et al. 1999). In theory, hydrated products can have massive interactions with $\mathrm{MgSO}_{4}$. The main products that are shaped due to these interactions are gypsum and magnesium hydroxide (MH) (Chegenizadeh et al. 2017; Collepardi 2003; Pye and Schiavon 1989; Damidot et al. 1992). Equation (1) shows these interactions;

$$
\mathrm{CH}+\mathrm{MS}+2 \mathrm{H} \rightarrow \mathrm{CSH}_{2}+\mathrm{MH}
$$

As result of converting calcium hydroxide to gypsum, cement get softened and its strength reduces. The generated gypsum interacts with aluminates products such as 3CSH or with its hydrated form known as mono-sulfate impacting ettringites arrangements and generates bundles of stretched fibers which causes some unusual expansion which is known as sulphate attack. Equation (2) shows the mentioned interactions;

$$
\mathrm{C}_{3} \mathrm{~A}+3 \mathrm{CSH}_{2}+26 \mathrm{H} \rightarrow \mathrm{C}_{3} \mathrm{~A}(\mathrm{CS})_{3} \mathrm{H}_{3}
$$

The main issue of this interaction is reducing the calcium hydroxide generation which causes reduction of the alkalinity. Generation of brucite increase of the mentioned reduction in $\mathrm{pH}$. Furthermore, as the brucite's has an insoluble nature, the reduction of calcium hydroxide generation is increased (Chegenizadeh et al. 2020; Chegenizadeh et al. 2017; Gruyaert et al. 2012; Anagnostopoulos 2007; Mangat and El-Khatib 1992). This interaction amongst magnesium sulfate and calcium hydroxide continues until a complete evacuation of $\mathrm{CSH}$ and reduction of the $\mathrm{pH}$ is happened. Reduction of $\mathrm{pH}$ as well as $\mathrm{CSH}$, as the essential hydration component of the strength in cement, discharges the existing calcium and substitutes by the magnesium. This process is known as declassification which produces a non-cementitious material known as magnesium silicate hydrate (MSH) subsequently (Chegenizadeh et al 2018; Irassar et al. 2000). As CSH reduces and MSH increases, the cement glue is diminished (Keramatikerman et al. 2018; 2017a; 2017b; Pacheco-Torgal and Jalali 2009; Dent 1986)

This research is in continuation of a collaborative project on application of bagasse ash in improvement of sulphate magnesium contaminated soil between Arup Australia and Curtin University (Mikhail et al. 2020; Keramatikerman et al. 2019). In addition, the paper has been continuation of research project of first author.

\section{USED MATERIALS}

The utilised cane ash in this study obtained from MSF Sugar,

Published By:

Blue Eyes Intelligence Engineering

\& Sciences Publication

(C) Copvriaht: All riahts reserved.

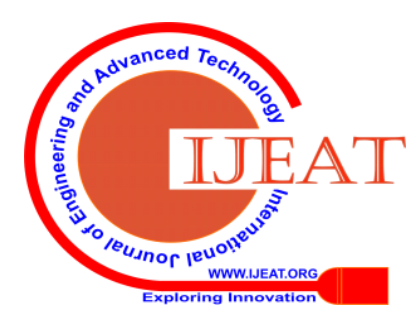


a manufacturer in Innisfail in North Queensland. The properties of utilized PC and clay as of now given in previous research (Mikhail et al. 2020).

\section{SAMPLE PREPARATION}

The UCS testing is the main geotechnical testing is utilized to assess compressive strength of the soil. In this test, a stress strain curve is generating for each sample which the peak point shows the highest amount of compressive strength value (Chegenizadeh et al. 2017).

Clay, cement and bagasse ash were completely mixed in dry mode, and then water was included to the blend until a homogenous mixture achieved. the added water for each mixture was based on the optimum moisture content (OMC) achieved from compaction test (Mikhail et al. 2020). Each mixture was cast into a mould with $43 \mathrm{~mm}$ Diameter and $83 \mathrm{~mm}$ height and compacted. Fig. 1 shows prepared specimens after curing time. The specimens were cured for 7 , 14 and 28 days in a proper environment as recommended by Chegenizadeh et al. (2017). After passing curing periods samples were placed in $\mathrm{MgSO}_{4}$ basin, with a solution recommended by Chegenizadeh et al. (2017). Fig. 2 shows submerged specimens in a magnesium sulphate basin.

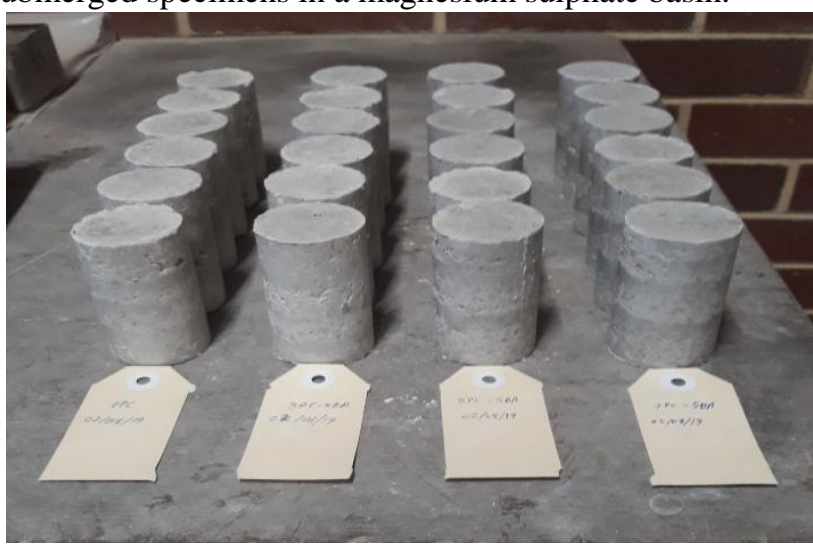

Fig. 1 Prepared UCS specimens before testing

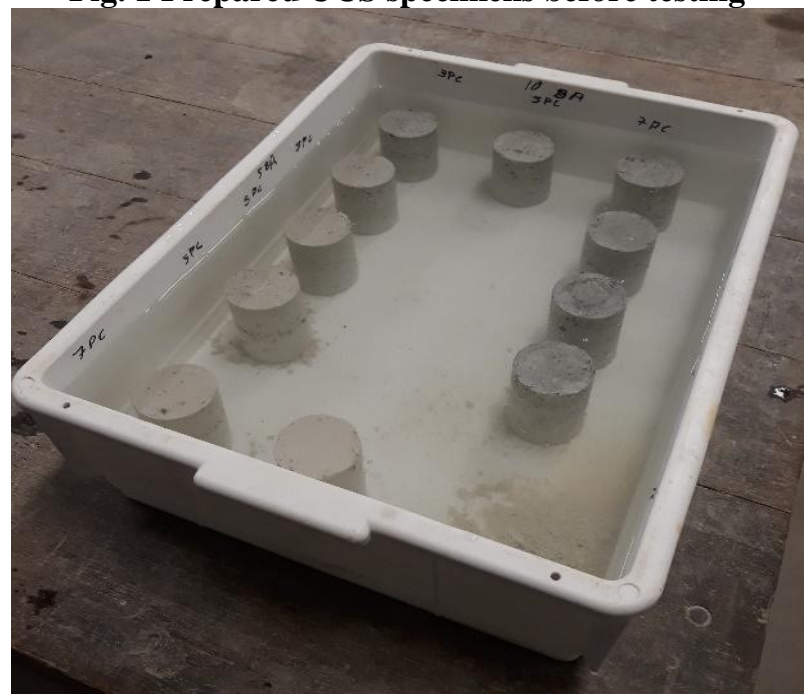

Fig 2. Specimens submerged in a magnesium sulphate basin

\section{TESTING PROGRAM AND METHODOLOGY}

A UCS device with up to $10 \mathrm{kN}$ compressive capacity was

utilized to perform the tests in accordance with Australian Standard. A compression rate of $1 \mathrm{~mm} / \mathrm{min}$ was employed according to Chegenizadeh et al. (2020) on 74 exposed and control specimens. Fig. 3 shows the UTM-14 machine employed in this study with a smashed sample. Also, Table 1 shows the testing program utilized to conduct the tests.

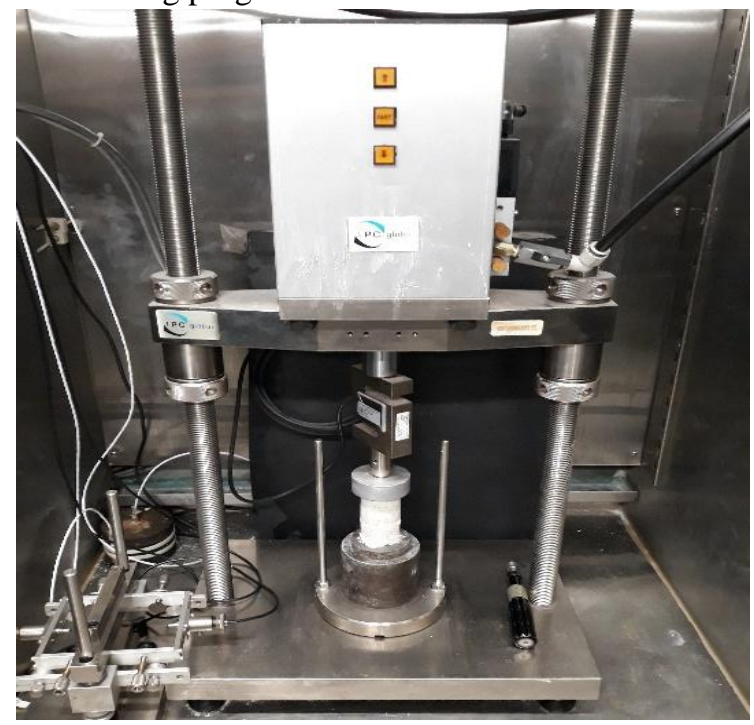

Fig. 3: Employed UCS testing machine in this study

TABLE 1:

LABORATORY TESTING PROGRAM

\begin{tabular}{|c|c|c|}
\hline ID & Cement (\%) & Bagasse ash (\%) \\
\hline K & - & - \\
\hline 3PC & 3 & - \\
\hline 5PC & 5 & - \\
\hline 7PC & 7 & 5 \\
\hline 3PC-5BA & 3 & 5 \\
\hline 5PC-5BA & 5 & 5 \\
\hline 7PC-5BA & 7 & 10 \\
\hline 3PC-10BA & 3 & 10 \\
\hline 5PC-10BA & 5 & 10 \\
\hline 7PC-10BA & 7 & 15 \\
\hline 3PC-15BA & 3 & 15 \\
\hline 5PC-15BA & 5 & 15 \\
\hline 7PC-15BA & 7 & \\
\hline
\end{tabular}

\section{RESULTS AND DISCUSSION}

A standard formula was used as recommended by prior researchers (Chegenizadeh et al. 2017) to assess the improvements. To compare the peak UCS values of the bagasse ash added specimens in benchmark and after sulphate attack the equation used in Chegenizadeh et al. (2016) was utilized.

\section{A. Effect of bagasse ash after 7 Days}


The UCS results for $\mathrm{MgSO}_{4}$ exposed specimens showed more improvement after addition of the bagasse ash. This changes $101.3 \%$ for the 5PC-15BA comes about with a peak UCS value of $0.54 \mathrm{MPa}$. In comparison, $1.17 \mathrm{MPa} q_{u}$ was recorded for unexposed 5PC-15BA sample. In fact, exposing specimens to $\mathrm{MgSO}_{4}$ reduced the strength however, at the same time, this increases the pozzolanic responses rate within the mixture having a higher exchange rate of calcium hydroxide through the soil to produce CSH and letting the bagasse ash particles to show their pozzolanic properties (Sargent 2015). The design is clearer when the comes about are charted as can be seen underneath in both Fig 4 and Fig. 5.

Amid the drenching handle within the magnesium sulfate arrangement, the $3 \%$ PC example was totally broken down as appeared on Fig. 6, in this manner, a rate enhancement was not calculated for the remaining 3PC examples hence anticipating a comparison between the examples. Table 2 and Table 3 show the rate of improvements.

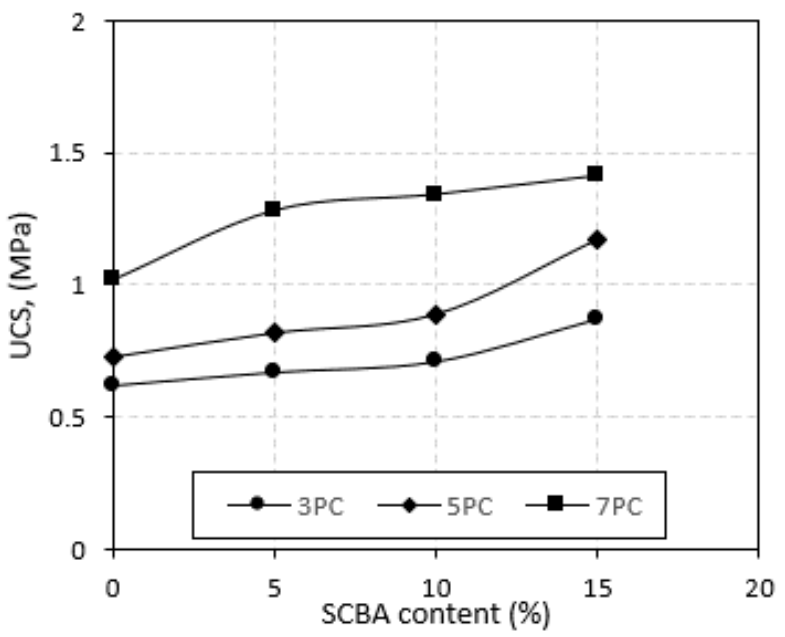

Fig. 4 Compressive strength tests for control specimens after 7-day curing

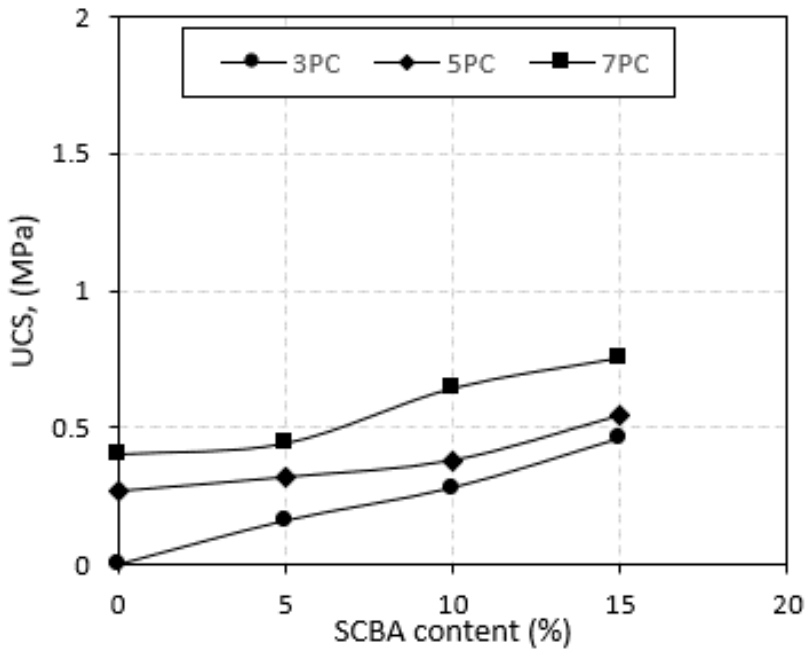

Fig. 5 Compressive strength tests for exposed specimens after 7-day curing

Table 2

CONTROL UCS VALUES AFTER 7-Day CURING

\begin{tabular}{|c|c|c|c|c|c|c|}
\hline \multirow{2}{*}{ SCBA \% } & \multicolumn{2}{|c|}{ ЗPC } & \multicolumn{2}{|c|}{$5 \mathrm{PC}$} & \multicolumn{2}{|c|}{$7 \mathrm{PC}$} \\
\hline & $\mathrm{q}_{\mathrm{u}}(\mathrm{MPa})$ & Imp (\%) & $\mathrm{q}_{\mathrm{u}}(\mathrm{MPa})$ & $\operatorname{Imp}(\%)$ & $\mathrm{q}_{\mathrm{u}}(\mathrm{MPa})$ & $\operatorname{Imp}(\%)$ \\
\hline 0 & 0.62 & - & 0.73 & - & 1.02 & - \\
\hline 5 & 0.67 & 8.1 & 0.82 & 12.3 & 1.28 & 25.5 \\
\hline
\end{tabular}

Published By:

Blue Eyes Intelligence Engineering

\& Sciences Publication

(C) Copvriaht: All riahts reserved.

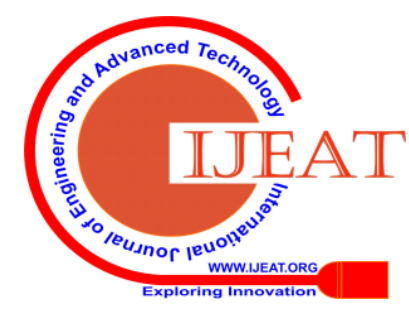


Bagasse ash is known as a pozzolanic material. The main characteristic of a pozzolanic material when mixing with Portland cement (PC) is to increase the strength of the sample during the time. This enhancement increases up to a specific time and then become constant. The increase in strength of the samples were recorded in 7, 14, and 28 days.

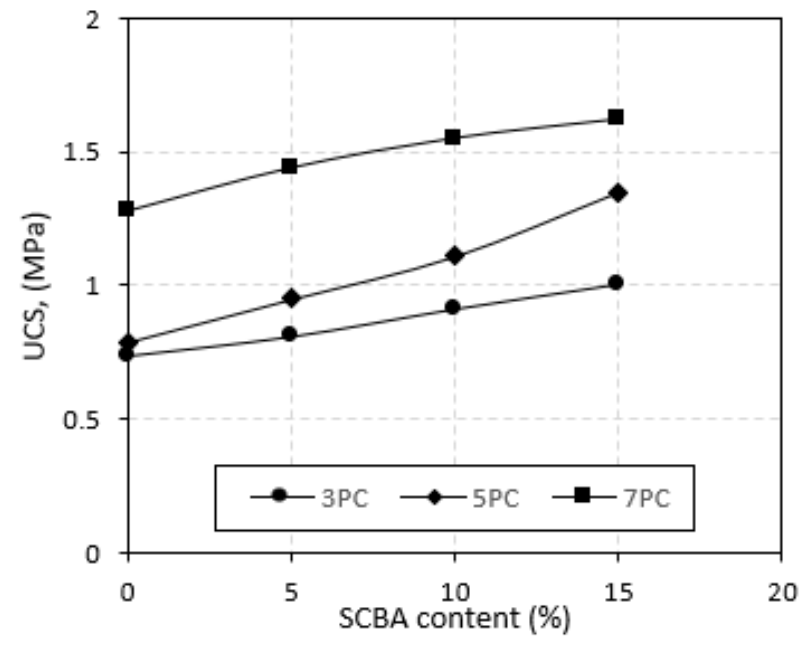

Fig. 7 Compressive strength of control specimens with 14-day curing

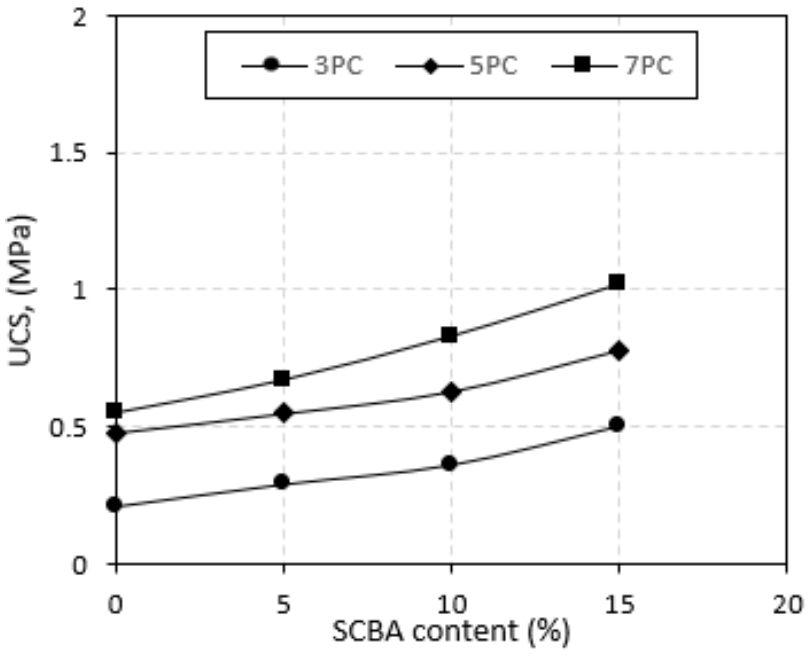

Fig. 8 Exposed compressive strength specimens after 14-day curing

TABLE 4

Unexposed Ucs Values After A 14 Day Curing Period

\begin{tabular}{|c|c|c|c|c|c|c|}
\hline \multirow{2}{*}{ SCBA \% } & \multicolumn{2}{|c|}{ 3PC } & \multicolumn{2}{|c|}{$5 \mathrm{PC}$} & \multicolumn{2}{|c|}{$7 \mathrm{PC}$} \\
\hline & $\mathrm{q}_{\mathrm{u}}(\mathrm{MPa})$ & $\operatorname{Imp}(\%)$ & $\mathrm{qu}_{\mathrm{u}}(\mathrm{MPa})$ & Imp (\%) & $\mathrm{q}_{\mathrm{u}}(\mathrm{MPa})$ & Imp (\%) \\
\hline 0 & 0.74 & - & 0.79 & - & 1.28 & - \\
\hline 5 & 0.81 & 10.00 & 0.95 & 20.25 & 1.44 & 12.50 \\
\hline 10 & 0.91 & 23.64 & 1.11 & 40.51 & 1.55 & 21.09 \\
\hline 15 & 1.00 & 35.45 & 1.35 & 70.9 & 1.62 & 26.56 \\
\hline
\end{tabular}

TABLE 5

EXPOSED UCS VALUES AFTER A 14 DAY CURING PERIOD

\begin{tabular}{|c|c|c|c|c|c|c|}
\hline \multirow{2}{*}{ SCBA \% } & \multicolumn{2}{|c|}{ ЗРC } & \multicolumn{2}{|c|}{$5 \mathrm{PC}$} & \multicolumn{2}{|c|}{ 7PC } \\
\hline & $\mathrm{q}_{\mathrm{u}}(\mathrm{MPa})$ & Imp (\%) & $\mathrm{q}_{\mathrm{u}}(\mathrm{MPa})$ & Imp (\%) & $\mathrm{q}_{\mathrm{u}}(\mathrm{MPa})$ & $\operatorname{Imp}(\%)$ \\
\hline 0 & 0.21 & - & 0.48 & - & 0.55 & - \\
\hline 5 & 0.29 & 38.10 & 0.55 & 14.58 & 0.67 & 21.82 \\
\hline 10 & 0.36 & 71.43 & 0.62 & 29.17 & 0.83 & 50.91 \\
\hline
\end{tabular}

\section{Effect of bagasse ash after 28-Days of Curing}

The outcome of 28-day curing shows higher positive changes as can be seen in Fig. 9 and 10. The achieved UCS values for the unexposed sample was around the $7 \%$ to $30 \%$. In addition, the exposed examples shown higher rate of improvement from $17.4 \%$ to $184 \%$. This fact could be seen in Table 6 and Table 7. Fig. 9 and Fig. 10 shows UCS testing before and after sulfate attack and after 28 days curing time.

However once more, the charts down underneath appear an increment within the crest UCS values with the increment in SCBA and advance fortifying this hypothesis. In spite of the fact that, another example broken up amid the dousing period which brought about in a plunge for the 5PC bend in as appeared in Fig 9, this did not anticipate the same slant from being watched for these comes about. Soak bends can be perceived from Table 8 whereas Fig. 7 has more level bends which is reliable with the 14-day comes about that shown the same drift.

Also, it appears that all the examples appeared a steady slant all through and shown changes which are unmistakable on all the charts. These enhancements appeared to be within the extend of roughly $10-35 \%$ for unexposed examples whereas uncovered examples extended generally from $60 \%$ to $180 \%$.

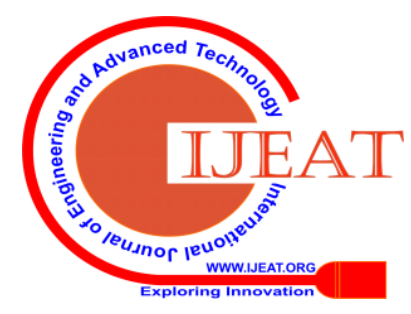




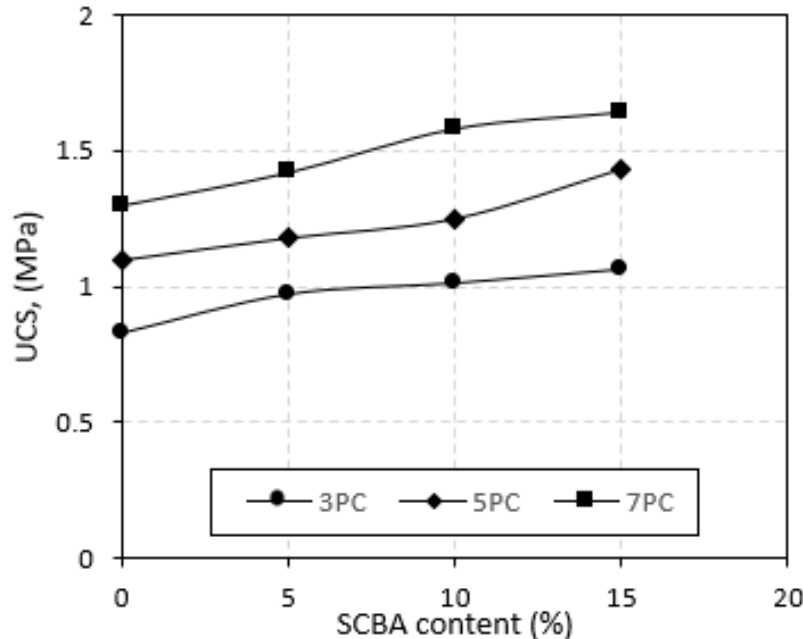

Fig. 9 Compressive strength values for exposed specimens after 28-day curing

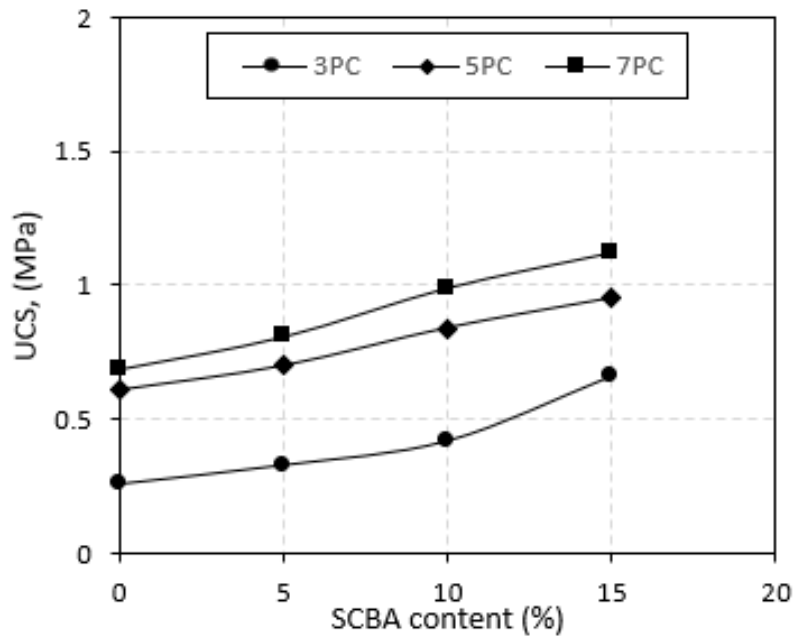

Fig. Compressive strength for unexposed specimens after 28-day curing

TABLE 6 Unexposed Specimens AFter 28 Day CuRING

\begin{tabular}{|c|c|c|c|c|c|c|}
\hline \multirow{2}{*}{ SCBA \% } & \multicolumn{2}{|c|}{ ЗРC } & \multicolumn{2}{|c|}{$5 \mathrm{PC}$} & \multicolumn{2}{|c|}{$7 \mathrm{PC}$} \\
\hline & $\mathrm{qu}_{\mathrm{u}}(\mathrm{MPa})$ & $\operatorname{Imp}(\%)$ & $\mathrm{q}_{\mathrm{u}}(\mathrm{MPa})$ & Imp (\%) & $\mathrm{qu}_{\mathrm{u}}(\mathrm{MPa})$ & $\operatorname{Imp}(\%)$ \\
\hline 0 & 0.83 & - & 1.1 & - & 1.3 & - \\
\hline 5 & 0.97 & 16.87 & 1.18 & 7.27 & 1.42 & 9.23 \\
\hline 10 & 1.01 & 21.69 & 1.25 & 13.64 & 1.58 & 21.54 \\
\hline 15 & 1.06 & 27.71 & 1.43 & 30.00 & 1.64 & 26.15 \\
\hline \multicolumn{7}{|c|}{ TABLE 7 EXPOSED SPECIMENS AFTER 28 DAY CURING } \\
\hline \multirow{2}{*}{ SCBA \% } & \multicolumn{2}{|c|}{$3 P C$} & \multicolumn{2}{|c|}{$5 P C$} & \multicolumn{2}{|c|}{$7 \mathrm{PC}$} \\
\hline & $\mathrm{q}_{\mathrm{u}}(\mathrm{MPa})$ & Imp (\%) & $\mathrm{q}_{\mathrm{u}}(\mathrm{MPa})$ & $\operatorname{Imp}(\%)$ & $\mathrm{q}_{\mathrm{u}}(\mathrm{MPa})$ & $\operatorname{Imp}(\%)$ \\
\hline 0 & 0.26 & - & 0.61 & - & 0.69 & - \\
\hline 5 & 0.33 & 26.9 & 0.7 & 14.8 & 0.81 & 17.4 \\
\hline 10 & 0.42 & 61.5 & 0.84 & 37.7 & 0.99 & 43.5 \\
\hline 15 & 0.66 & 153.8 & 0.95 & 55.7 & 1.12 & 62.3 \\
\hline
\end{tabular}

\section{Effect of Curing Time}

Fig. 11 and Fig. 12 shows the impact of bagasse ash addition and curing time on change of the UCS values. As appeared, the crest UCS comes about expanded with an increment within the curing time. An indistinguishable drift was watched for the remaining bagasse ash compositions and for the exposed specimens, however with a lower UCS value. This increment is once more credited to the nature of the interactions happen and the generation of hydration products, subsequently, shaping more ties between the soil and the bagasse ash particles (Keramatikerman et al.; 2018c; Horpibulsuk et al. Morsy et al. 2011; 2010).

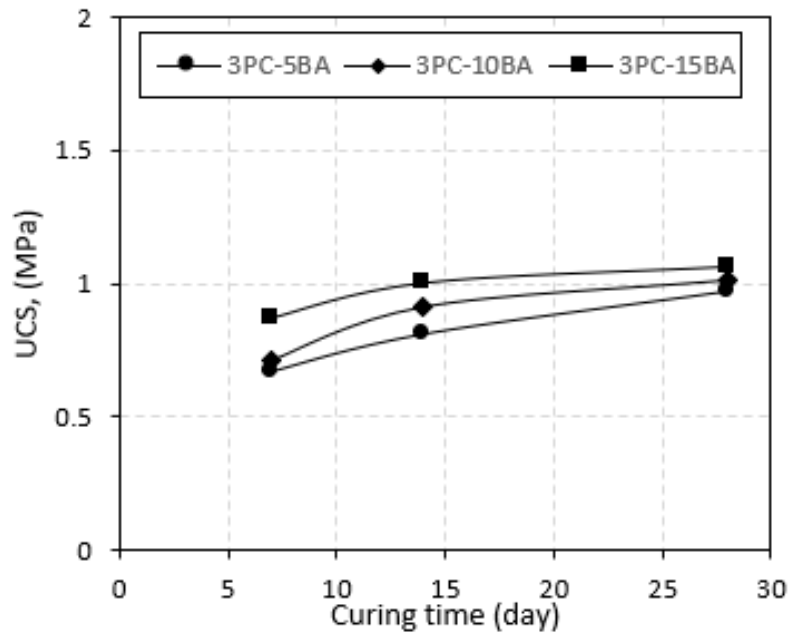

Fig.11 Unexposed specimens containing 3\% PC mixed with 5,10 and $15 \%$ bagasse ash

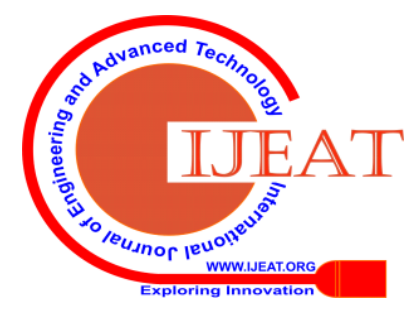


Application of Cane Ash on Compressive Strength of Soil Uncovered to $\mathrm{MgSO}_{4}$

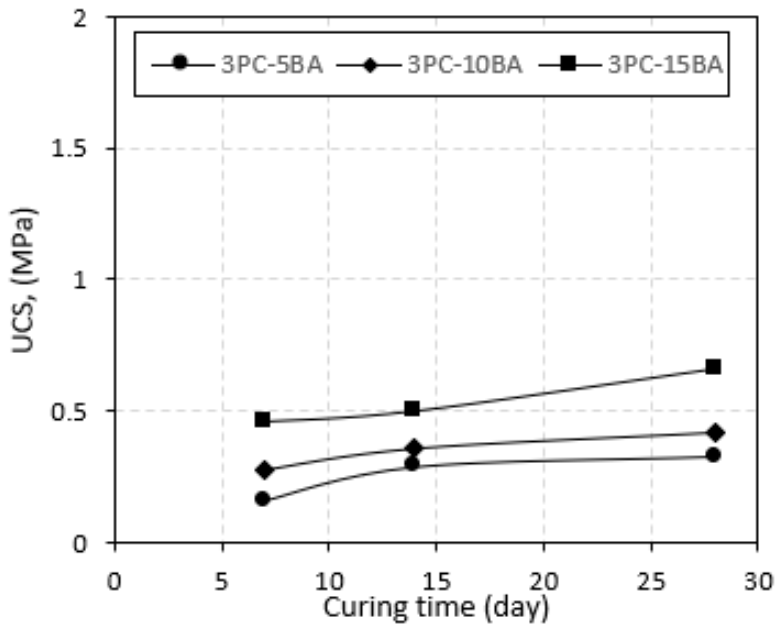

Fig. 12 Exposed specimens containing 3\% PC mixed with 5,10 and $15 \%$ bagasse ash

\section{E. Microstructural Analysis}

The tests were performed on the 7\% PC blended $15 \%$ bagasse ash samples to supply an arrangement of tall amplification pictures, earlier to and after presentation to $\mathrm{MgSO}_{4}$ arrangement.

From Fig. 13, which appears the comes about between the tests at 150x amplification, Essentially, with the amplification expanded to 3000x, as seen in Fig. 14 underneath, it isn't clear sufficient to perceive any microstructural intelligent or obvious contrasts between the two tests. As seen, era of the hydration items and arrangement of the concave is clear in higher amplification pictures which can be ascribed to expanding and diminishment of the UCS values in uncovered and unexposed examples separately.

Generation of the hydration products can are apparent in both uncovered specimens. Also, formation of the depression on exposed samples can be seen from the exposed figures as shown in the below figures.

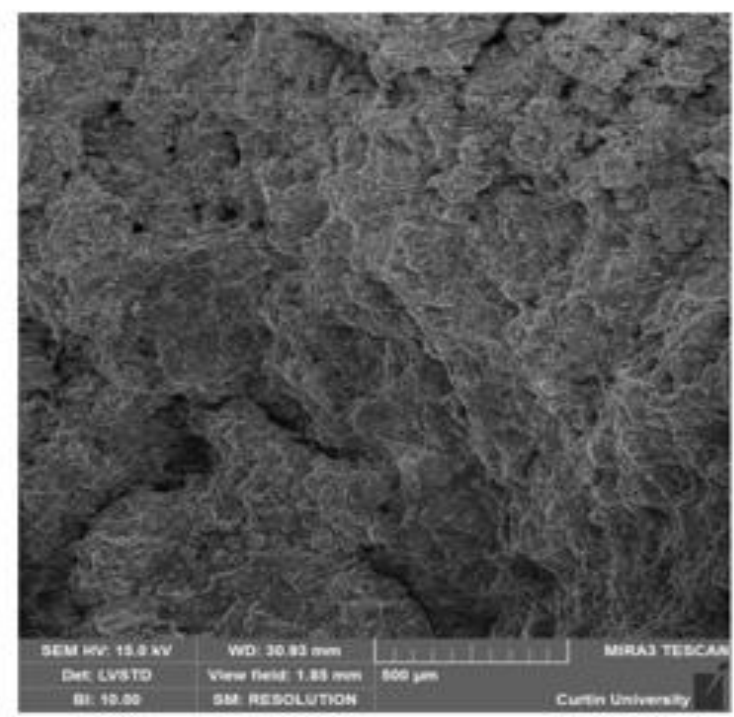

(a)

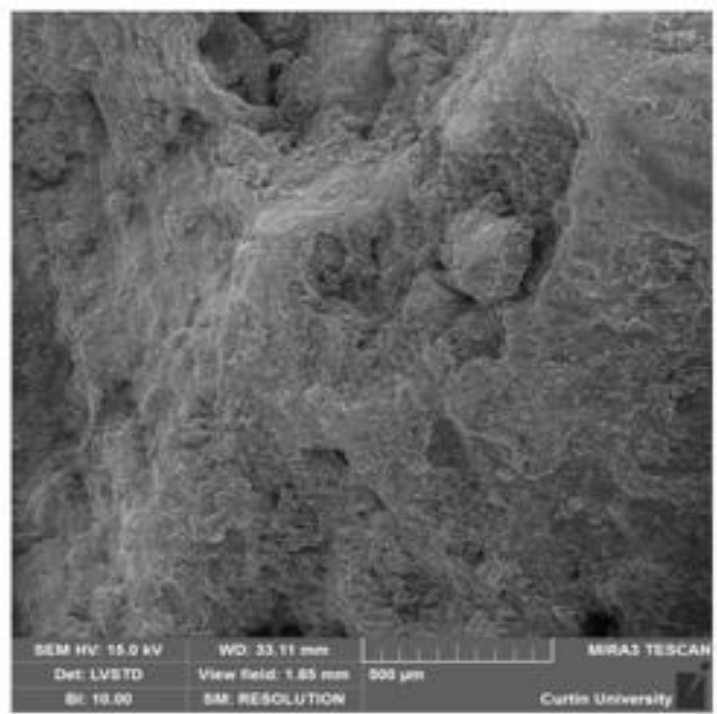

(b)

Fig. 13 SEM for 7PC-15BA for (a) unexposed specimen; (b) exposed specimen at a lower zooming

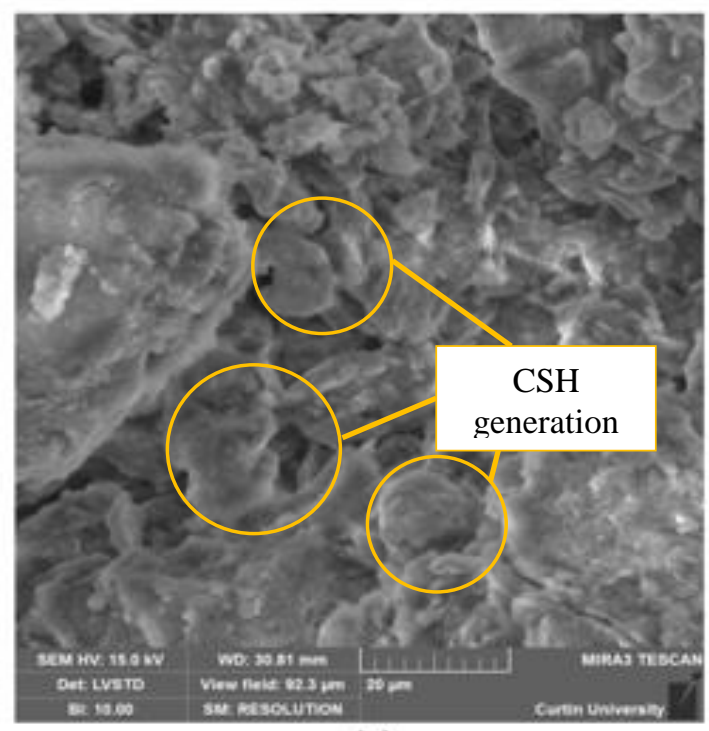

(a)

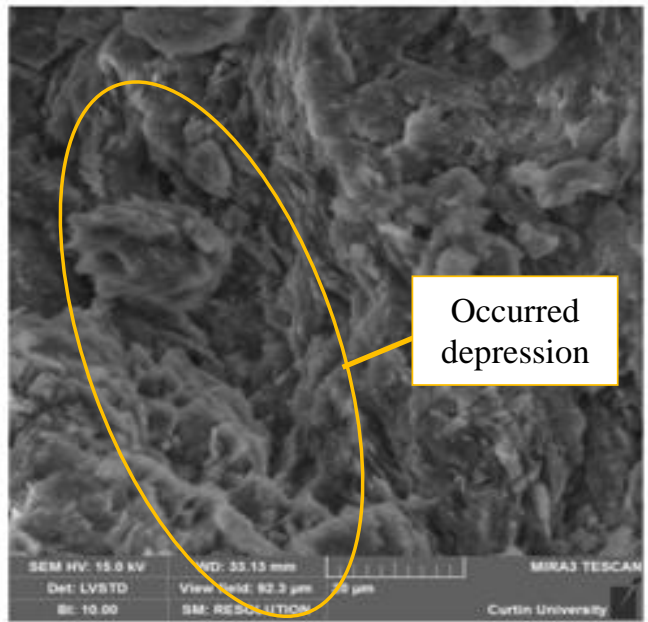

(b)

Fig. 14 SEM analysis for 7PC-15BA for (a) unexposed specimen; (b) exposed specimen at higher zooming

Published By:

Blue Eyes Intelligence Engineering \& Sciences Publication

DOI: 10.35940/ijeat.D6643.049420

Journal Website: www.ijeat.org

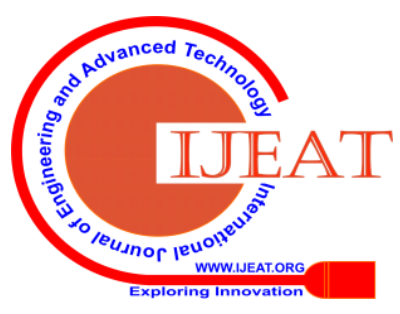




\section{CONCLUSIONS}

Below results can be concluded from the conducted study on effect of bagasse ash on improvement of the acid sulphate contaminated soils.

- Magnesium sulfate uncovered examples shown a noteworthy rate increment extending up to almost $154 \%$, exhibiting that an increment within the SCBA of the blend can be viable in expanding the UCS quality after presentation to sulfate.

- Increasing cement content, bagasse ash, and curing periods are effective to improve compressive strength of soil

- The SEM investigation given as a supporting prove for arrangement of the CSH items in unexposed tests and forming concave and discouragements in uncovered examples.

- $\quad$ Bagasse ash is a useful byproduct and its application is recommended as a pozzolanic product along with the cement to improve the compressive strength of soil.

The consider appeared that expansion of sugarcane bagasse cinder can emphatically influence the compressive quality of the tried tests and its application is prescribed.

\section{REFERENCES}

1. Al-Rkaby AHJ, Chegenizadeh A, Nikraz H. (2016). Directional-dependence in the mechanical characteristics of sand: a Review, International Journal of Geotechnical Engineering 10 (5), 499-509

2. Al-Rkaby AHJ, Chegenizadeh A, Nikraz H. (2017). Anisotropic strength of large scale geogrid-reinforced sand:experimental study, Soils and foundations 57 (4), 557-574

3. Anagnostopoulos, C. A. (2007). Cement-clay grouts modified with acrylic resin or methyl methacrylate ester: Physical and mechanical properties. Construction and Building Materials, 21(2), 252-257.

4. Chegenizadeh A, Keramatikerman M, Panizza S, Nikraz H. (2017). Effect of powdered recycled tire on sulfate resistance of cemented clay. Journal of Materials in Civil Engineering. 2017 Oct 1;29(10):04017160.

5. Chegenizadeh, A., Nikraz, H. (2011a). Investigation on strength of fiber reinforced clay Advanced Materials Research 261-263, pp. 957-963.

6. Chegenizadeh, A. and H. Nikraz, (2011b). Study on modulus of elasticity of reinforced clay - Advanced Materials Research. 243-249: pp. 5885-5889, 2011.

7. Chegenizadeh, A. and H. Nikraz, (2011c). Composite Soil: Fiber Inclusion and Strength, Journal of Advanced Materials Research 1646

8. Chegenizadeh, A. and H. Nikraz, (2012). Composite Clayey Sand and Short Fiber, Advanced Materials Research 383, 2764-2769

9. Chegenizadeh, A., Keramatikerman, M., Dalla Santa, G., \& Nikraz, H. (2018). Influence of recycled tyre amendment on the mechanical behaviour of soil-bentonite cut-off walls. Journal of cleaner production, 177, 507-515.

10. Chegenizadeh, A., Keramatikerman, M., Miceli, S., Nikraz, H., Salih Sabbar, A. (2020). Investigation on Recycled Sawdust in Controlling Sulphate Attack in Cemented Clay. Appl. Sci., 10, 1441.

11. Chegenizadeh, A., Keramatikerman, M., Panizza, S., \& Nikraz, H. (2017). Effect of powdered recycled tire on sulfate resistance of cemented clay. Journal of Materials in Civil Engineering, 29(10), 04017160

12. Collepardi, M. (2003). A state-of-the-art review on delayed ettringite attack on concrete. Cement and concrete Composites, 25(4-5), 401-407.

13. Damidot, D., Atkins, M., Kindness, A., \& Glasser, F. P. (1992). Sulphate attack on concrete: limits of the AFt stability domain. Cement and concrete research, 22(2-3), 229-234.

14. Dent, D. L. (1986). Acid sulphate soils: a baseline for research and development (No. 39). ILRI.

15. Gruyaert, E., Van den Heede, P., Maes, M., \& De Belie, N. (2012). Investigation of the influence of blast-furnace slag on the resistance of concrete against organic acid or sulphate attack by means of accelerated degradation tests. Cement and Concrete Research, 42(1), 173-185.

16. Hasan U, Chegenizadeh A, Budihardjo M, Nikraz H (2015) A review of the stabilisation techniques on expansive soils Aust. J. Basic Appl. Sci 9, 541-548

17. Horpibulsuk, S., Rachan, R., Chinkulkijniwat, A., Raksachon, Y., \& Suddeepong, A. (2010). Analysis of strength development in cement-stabilized silty clay from microstructural considerations. Construction and building materials, 24(10), 2011-2021.

18. Irassar, E. F., Gonzalez, M., \& Rahhal, V. (2000). Sulphate resistance of type V cements with limestone filler and natural pozzolana. Cemen and Concrete Composites, 22(5), 361-368.

19. Kalıpcilar İ, Mardani-Aghabaglou A, Sezer Gİ, Altun S, Sezer A (2016). Assessment of the effect of sulfate attack on cement stabilized montmorillonite. Geomechanics and Engineering. Jun 1;10(6):807.

20. Keramatikerman M, Chegenizadeh A, Nikraz H. (2017a). Experimental study on effect of fly ash on liquefaction resistance of sand Soil Dynamics and Earthquake Engineering 93, 1-6

21. Keramatikerman, M., Chegenizadeh, A., \& Nikraz, H. (2017b). An investigation into effect of sawdust treatment on permeability and compressibility of soil-bentonite slurry cut-off wall. Journal of Cleaner Production, 162, 1-6.

22. Keramatikerman M, Chegenizadeh A, Terzaghi S. (2019) Review on Effect of Sugarcane Bagasse Ash as an Additive in Construction Industry. 2019. EJGE. Vol.24 Bun. 02.

23. Keramatikerman, M., Chegenizadeh, A., Nikraz, H., \& Sabbar, A. S (2018). Effect of flyash on liquefaction behaviour of sand-bentonite mixture. Soils and foundations, 58(5), 1288-1296.

24. Mangat, P. S., \& El-Khatib, J. M. (1992). Influence of initial curing on sulphate resistance of blended cement concrete. Cement and Concrete Research, 22(6), 1089-1100.

25. Mikhail, M., Keramatikerman, M., Chegenizadeh, A., Terzaghi, S., Burns, G., Nikraz, H. (2020). Influence of Bagasse Ash on Compaction Behvaiour of Soil. International Journal of Innovative Technology and Exploring Engineering (IJITEE). 9(5).

26. Mohamad, N. O., Razali, C. E., Hadi, A. A. A., Som, P. P., Eng, B. C., Rusli, M. B., \& Mohamad, F. R. (2016). Challenges in construction over soft soil-case studies in Malaysia. In IOP conference series: materials science and engineering (Vol. 136, No. 1, p. 012002). IOP Publishing.

27. Morsy, M. S., Alsayed, S. H., \& Aqel, M. (2011). Hybrid effect of carbon nanotube and nano-clay on physico-mechanical properties of cement mortar. Construction and Building Materials, 25(1), 145-149.

28. Pacheco-Torgal, F., \& Jalali, S. (2009). Sulphuric acid resistance of plain, polymer modified, and fly ash cement concretes. Construction and Building Materials, 23(12), 3485-3491.

29. Pye, K., \& Schiavon, N. (1989). Cause of sulphate attack on concrete, render and stone indicated by sulphur isotope ratios. Nature, 342(6250), 663-664.

30. Rollings RS, Burkes JP, Rollings MP. (1999). Sulfate attack on cement-stabilized sand. Journal of geotechnical and geoenvironmental engineering. 1999 May;125(5):364-72.

31. Sabbar, A.S., A. Chegenizadeh, and H. Nikraz, (2017). Static liquefaction of very loose sand-slag-bentonite mixtures. Soils and Foundations. 57(3): p. 341-356

32. Sargent P. (2015). The development of alkali-activated mixtures for soil stabilisation. In Handbook of alkali-activated cements, mortars and concretes 2015 Jan 1 (pp. 555-604). Woodhead Publishing.

33. Snedker EA, Temporal J. (1990). M40 motorway banbury IV contract-lime stabilisation. Highways \& Transportation. 1990 Dec;37(12).

\section{AUTHORS PROFILE}

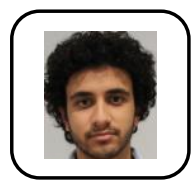

Mark Mikahil was with Curtin University Bentley Campus in Perth, Western Australia (e-mail: mark.mikhail@undergrad.curtin.edu.au).

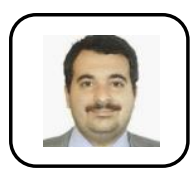

Dr. Amin Chegenizadeh is senior lecturer in civil and mechanical engineering schools in Curtin University,His area of expertise fall into soil mechanics and pavement engineering.

Published By:

Blue Eyes Intelligence Engineering

\& Sciences Publication

(C) Copvriaht: All riahts reserved.

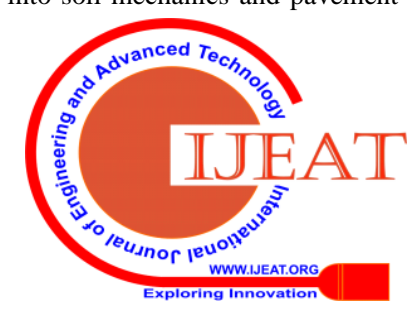


Dr. Mahdi Keramatikerman is with Arup Australia, Queensland, Australia. (Corresponding author: Phone: +61 74421 4820, e-mail: mahdi.keramati@arup.com).

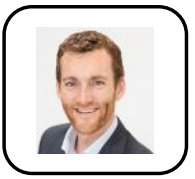

Geoffrey Burns is a Geotechnical Lead with Arup Australia, Queensland, Australia. (e-mail: geoffrey.burns@arup.com).

Sergei Terzaghi is a Geotechnical Lead with Arup America, Los Angeles, USA. (e-mail: sergei.terzaghi@arup.com).

Professor Hamid Nikraz is an emeritus professor in civil and mechanical engineering schools in Curtin University, Australia.

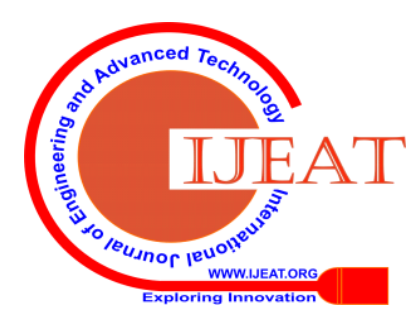

